\title{
IMPLEMENTATION OF SCIENTIFIC, ANALYTICAL AND APPLIED TOOLS OF ORGANIZING INVESTMENT IN A MODERN DEVELOPMENT SYSTEM
}

\author{
Ryzhakova G. M.
}

\section{INTRODUCTION}

In recent years, the construction industry in Ukraine demonstrates a consistent tendency towards the growth of a significant number of financially incapable and failing enterprises unable to fulfil their obligations before customers, investors and creditors timely and to the full extent. Such situation has exacerbated under the influence of the global financial and economic crisis and has had an impact on almost all kinds of economic activities of the construction market players. An efficient system to prevent bankruptcy is crucial, especially in the times of economic crisis, when economic entities face the loss of capital, payment crisis, decline in production, shrinkage in capacities, and closure of work places, which gives rise to economic and social problems in their further functioning.

Theoretical aspects of investment and issues of government regulation of investment activities were elaborated on in the works of such authors as H. Alexander, J. Bailey, V. Berence, J. Brigham, S.D. Bushuiev, V.M. Heietz, A.F. Hoiko, Ya.A. Zhalilo, J. Canes, F. Kene, P.M. Kulikov, T. Kun, T.S. Marchuk, M.I. Tuhan-Baranovskyi, V.O. Pokolenko, G.M. Ryzhakova, L.V. Sorokina, S.P. Stetsenko, V.H. Fedorenko, D.O. Chernyshev, Yu.A. Chupryna, J.R. Hicks, S.M. Shkarlet, W. Sharpe. However, a number of unstudied issues remain despite a rather extensive exploration of many theoretical and methodological issues and practical developments concerning the mechanisms of the state regulation of investment activities in various spheres of economy, including in the sphere of state-controlled development. Giving a credit to the scientific, practical and methodological contribution made by the mentioned scholars, it should be mentioned that the analytical framework for forming an economic outline of the investment mechanisms and provision of investment resources for real investments do not meet the current requirements of preparation and implementation of the residential development cycle from initiation to commissioning of residential and property developments. The most urgent need on the agenda is the need to renovate the methodological approach and tools for selecting economically sustainable mechanisms of residential 
development and search for rational variants of investment support for residential development projects.

The problems of investment in construction sphere are of immediate interest, as the reference points determined by the market economy development, tightening the market requirements to technical and economic offers in construction, the necessity for building projects to meet a wide range of investment resources, growing possibilities of architectural and construction practice, social needs of the population. The changeover to a new type of economy in Ukraine necessitated an overview of investment and construction companies' activities. Currently, the activities of these structures are formed within an investment portfolio, which makes it necessary for developers to search for investors, thoroughly assess each project, form mutually profitable alliances with business partners, search effective tools of promoting goods on the market etc. Many domestic and foreign scholars tackle the issue of improving the methods of investment management, which highlights the salience of this issue and its significance for the further development of market relations, as well as of economic and architectural and construction sciences.

Hence the applied scientific aim of this research is the development of a conceptual model of a problem-oriented differentiated choice of sources of resourcing of investment and construction projects in housing construction, a high-quality and user-friendly assessment mechanism, striking a balance and managing the social value of housing along with its monetary value.

\section{Conceptual model of a differentiated attraction of resourcing sources of investment and construction projects}

In the current context, construction industry is one of the most requested by the society and state due to its social orientation and investment requirement. Investment processes in the construction sphere must provide a sufficient recovery of enterprises' means of production, kinds of economic activity within the national economy through creating new objects, expanding existing facilities, ensuring their reconstruction or technical reequipment. Construction is one of the largest consumers of adjacent markets' products (chemicals and chemical raw materials, mechanical, electric and other kinds of equipment) and related services. As the construction sphere has such economic significance and is so deeply integrated in related kinds of economic activities, its level of development has a considerable impact of the state of economy as a whole. Also, investing in construction allows to solve important social and economic problems: providing citizens with housing, modernizing obsolete communal infrastructure, renovating housing stock, constructing and reconstructing amenities. A weak investment activity on the part of the state, enterprises 
and population, high intra-industry competition and monopoly of certain construction companies, administrative red tape, as well as failings of technical regulation, lack of balance between construction norms and regulations with international standards negatively impact business activities in the construction sphere.

Today, management of investment and construction projects in housing construction sphere (ICPHC) in Ukraine faces a vast uncertainty and constantly growing complexity of market environment of the projects, high risks of their implementation, lack of funds for financing and low purchasing power of housing consumers, low quality of construction works, imperfect legislative and regulatory framework in the sphere and other difficulties. On the other hand, consumers face the lack of high-quality and affordable housing on the market. Many housing construction projects have been put on hold or frozen. In Ukraine, state programs aimed at providing housing to citizens are ineffectual or underfinanced. Despite the fact that around $60 \%$ of housing construction (HC) in Ukraine is financed by citizens' own money, even the least risky financing schemes lead to failure of projects in over $12 \%$ of cases ${ }^{1}$. The problem of improving the provision of population of Ukraine with high-quality, affordable housing with minimal risks of housing project implementation is undoubtedly top of the agenda. According to the scientific research hypothesis, to solve this problem, principles of managing ICPHC should be reviewed along with the obvious measures to stabilize economy, attracting investments, improvement construction-related legislation, rising the living standards for population etc., using project management tools, stakeholder theory, and evolutionary axiology. Emphasis should be shifted from the maximization of construction companies' profit through building residential objects to raising the level of satisfaction with the results of socially meaningful housing projects for all their stakeholders. The principle of striking a balance of interests of all stakeholders used both within separate construction project and within the whole branch, will promote further development of the construction sector of economy as a driving force of the economy at large, rather than principles of maximizing the profit of one of the project stakeholder. The system of ICPHC management requires a more detailed research and improvement. Due to a large number of failed projects, it is necessary to review the approaches to $\mathrm{HC}$ management. To circumvent the ideas of profit maximization, the value of housing projects (HP) should be expressed in non-financial indicators. The system of value-oriented HP management should encompass a period

1 Residential housing financing schemes in Ukraine. Special features of attracting investments into construction [Electronic resource] // Materials of KLN Consult web-site // Available at: http://www.kln.com.ua/content/view/87/102/lang,ua 
from the investment idea of the project to de-commissioning of a residential building. Defining the value of investment and construction housing projects in non-financial indicators is very important for socially significant housing projects. Successful construction of housing which provides value for all stakeholders has a great social relevance for the population of the country in need of such housing ${ }^{2}$.

The development of national economy depends much on the level of investment activity of domestic enterprises. Finding the ways to mobilize domestic sources of financing investment projects and attracting investment resources in the production are essential pre-requisites for the activation of investment activities of domestic enterprises, their stable development, rising the competitiveness of the domestic industry, and economic recovery for Ukraine overall. The formation of developer companies as integrated production units on the construction market enables the activization of investment activities of enterprises thanks to the scale and synergy effect, by pooling the financial, material, labor, intellectual and information potential of the enterprises participating in the integrated structure, and engaging it in the investment process.

A retrospective view of the development of the methods of economic assessment of investment financing sources established that the first economic assessment methods for investment programs were approximate solutions providing for a certain search of projects and variants of implementation thereof. The second group of methods was formed by the methods of validation of investment programs and financing thereof by the criterion of the improvement of the investor's situation. The third group consists of the most widely spread modifications of the investment sources selection method based on a certain set of characteristics: price and resource availability, financial risks, loss of control over the enterprise management. However, the methodologies for evaluating the innovative and investment activities of construction enterprises and attraction of financing sources were not used by these methods ${ }^{3}$.

Economic assessment of financing sources is a kind of management activity which allows to detect and measure, by using respective methodological tools, the basic cause-and-effect relations between the innovative and investment activities and attracting sources of financing thereof, to determine, within and outside of the enterprise, the main ways

${ }^{2}$ A.I. Rybak. Value-based management of investment and construction residential projects [Text] / A.I. Rybak, I.B. Azarova // Management of complex systems development. - 2013. № 24. - pp. $49-56$.

3 Residential housing financing schemes in Ukraine. Special features of attracting investments into construction [Electronic resource] // Materials of KLN Consult web-site // Available at: http://www.kln.com.ua/content/view/87/102/lang,ua - pp. 82-87. 
and mechanisms of reaching the milestones or expected results of resourcing innovative and investment activities depending on the depth of the enterprises' need for resources and the functionality of their sources.

The existing tools of economic assessment of financing sources are in fact built upon factoring in of two important aspects: the economic substance of the price and its connection with the expenditures related to the attraction of sources. It is the price of the source which is a priority tool for its economic assessment, which is used in the process of innovative and investment activities to: select the financing methods and sources based on the comparison of prices thereof; form a better structure of financing sources; capital budget planning; use in establishing the economic feasibility of investments as a discount rate. Unfortunately, the existing approaches do not present the price as an economic assessment tool to evaluate other conditions for attracting investment sources and characterizing them from the enterprise's point of view as to the source's availability and effects of its use.

The differential approach, described as an alternative way of economic assessment and source attraction, is free of such deficiencies. It allows to range the financing sources both from the point of view of quantitative analysis and from the point of view of qualitative factors influencing the adoption of decisions dealing with innovations and investment. Its implementation and feasibility are based on the expert evaluation results.

The use of the differential approach to the economic assessment of financing sources and alternative resources allows to: a) define the really necessary total amount of finances for the project implementation, which is substantially lower than the perceived amount; b) find more variants of attracting the sources of resources and asses alternative resources and sources thereof; c) reduce the time for choosing the sources, their assessment, and cut the cost thereof.

It is proposed to use the problem-oriented choice of sources of financing depending on the goals and tasks of the enterprise development (fig. 1)

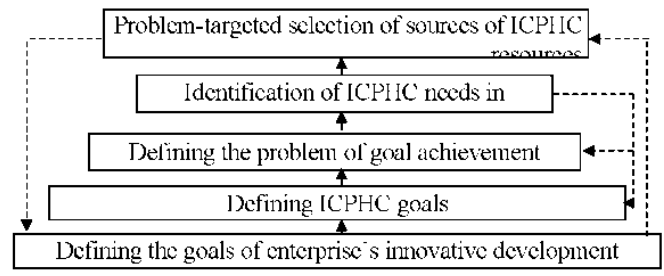

Fig. 1. A simplified conceptual model of differentiated attraction of resourcing sources 
The theoretical framework of the approach is created by: a) the hierarchy of the sources of financial and alternative resources, resourcing; b) classification of sources and factors of impact on the economic assessment and attraction of financing sources; c) classification of main goals; d) indicators' functional capabilities for economic assessment and source attraction ${ }^{4}$.

The sources of resourcing are a set of economic units and their attributes capable of providing a range of resources which satisfy its needs. The sources of financing are a set of economic units capable to providing a range of financial resources which satisfy its financial needs. The sources of alternative resources are a set of business entities and their attributes potentially capable of providing a range of resources in kind which satisfy certain naturalized needs and are capable to substitute financial resources for a certain time or permanently. The choice of the sources of resourcing is made in four spheres, each of which has its own conditions, limitations and indicators: internal and external sources of financial and alternative resources.

Similarly, goals have two basic characteristics of classification: a) directionality or nature. Goals may be of market, production, organization, economic, social and environmental directionality; b) event horizon, by which they are classified into current and project ones. Current goals include the set of current goals of all of the enterprise's innovative and investment projects at different implementation stages. Project goals are the goals of one specific project only.

The scheme of a construction enterprise's goals of innovative and investment activities gets into its final form when it is drawn out with due regard of individual characteristics of an enterprise: its mission, size, state, current or project directionality of goals, special features of the region and area it operates in.

When choosing a development goal, a construction enterprise determines the sphere where it will implement its innovative and investment activities. The goal and the sphere, in their turn, determine the issues to be tackled by the construction enterprise.

This is taken account of by the proposed conceptual model of a problemtargeted differentiated choice of resourcing sources for ICPHC, presented in a simplified (fig. 1) and full (fig. 2) forms.

\footnotetext{
${ }^{4}$ Pokolenko V.O. Introducing the tools for choosing the alternatives of construction project implementation by functional and technical integrity of implementing organizations / Pokolenko V.O., Ryzhakova G. M., Prykhodko D.O. // Management of complex systems development. 2014. - Issue 19. - pp. 104-108.
} 


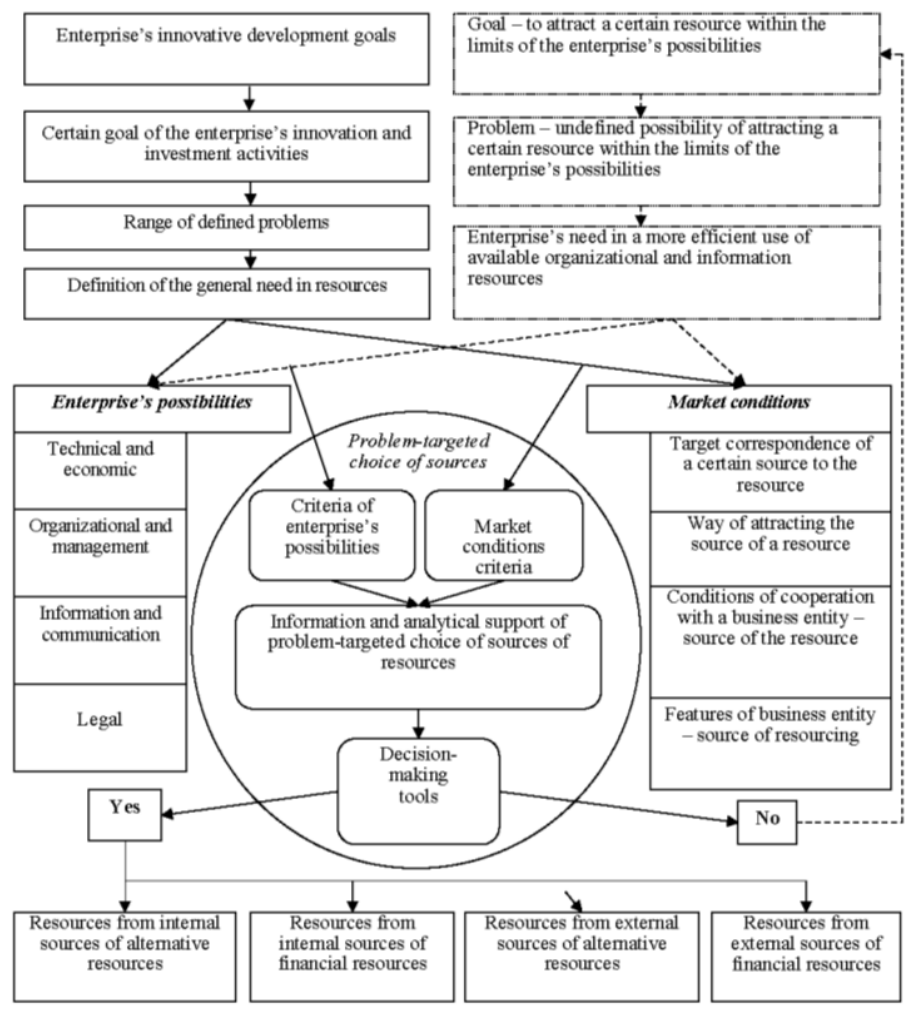

\section{Fig. 2. A full conceptual model of problem-targeted differentiated choice of resourcing sources}

The scientific and analytical approach to administering the operational activities of enterprises participating in the system of investment support of residential construction constitutes the essence of the analytical technology and tools for accommodating the contents and order of the processes of investment support of residential housing with the productivity of the operational activities of enterprises (developers) participating in the project, implemented and substantiated in this work.

The mentioned technology and tools are implemented through a system of the following structural and analytical components integrated into a single formalized decision-making system:

- the first component (component A) in the implemented technology is an economical, managerial, structural and hierarchical model "Economic, administrative and structural topology of interaction between enterprises 
participating in a housing construction project" which proposes alternative variants of economic and managerial interaction between participating enterprises during the cycle of creating value of a residential construction project;

- the next component (component B) within the implemented technology is an economic, structural and analytical model "Structuring of the contents, order and budget of investment into residential construction by participating enterprises";

- the final component (component C) - a model titled "Investment $\rightarrow$ project $\rightarrow$ participating enterprise» within the presented approach formally reflects the impact of the rates of a project's investment support and its economic and administrative environment on the functional and economic performance of certain enterprises participating in the project and their liquidity and solvency level.

\section{Investment determinants in the context of sustainable development: tactical and strategic aspects}

At the current development stage of the construction sphere, the synergetic basis of the elements of the processes of construction organization and management is increasing significantly. Virtually no significant investment and construction project is realized today without a collaborative component on the level of management, resource and information interaction between the processes of project development and construction, their document, regulatory and technical and technological support. In this sense, there is a necessity to build a system to form innovative competency in the field of system engineering, economics, construction organization and management. Overall, today construction management is improving towards the development of organizational systems formalizing business processes and forming consistent contractual relationships, which becomes a decisive factor of innovative development on the level of investors and building contractors. Multidimensional project management systems integrated with the systems of modelling and managing the life cycle of objects of a new level will allow to ensure the necessary quality of the object and process analysis and managerial decisions, including the deployment of cost management, construction terms, investment and project risks. Introduction of project management on the basis of modern information models has to facilitate the fulfilment of the innovative development of the construction sphere.

Within the sustainable development concept, a new approach to projecting and constructing objects has emerged, which is called sustainable projecting. It allows integration, analysis and optimization of ecological, technological, social and economic factors at every stage of the projecting process, a wide use of energy-saving technologies and renewable resources, including a closed circle of resource consumption, a harmonious inclusion of 
a new house into the environment and many more aspects which have to minimize the negative influence of human activity on the environment.

If the laws of interaction between the society and the nature are not taken account of properly, urban development entails significant (anthropogenic and technogenic) impact on the natural environment, which threatens catastrophic ramifications for biosphere and humans. Based on the results of the analysis, a conclusion is made on the necessity to accept a new urban development policy and introduce biosphere-compatible technologies in the construction and reconstruction of urban facilities.

The intensification of anthropogenic influence on the environment, coupled with the depletion of its assimilation potential, utter exacerbation of ecological problems in the conditions of depletion of non-renewable fuel and energy resources compels many researches to speak about the imminent ecological and humanitarian catastrophe ${ }^{56}$.

Investment and construction sector is one of the largest consumers of energy resources forming human environment. Therefore, it is necessary to organize such system for functioning of enterprises of territorial investment and construction sector, which will ensure that the development of construction, including residential construction, will be premised on the comparison of its human influence on nature (considering the balance of needs and possibilities of construction enterprises, developers and contractors) and environment sustainability with their influence. The implementation of such conceptual approach requires a transformation of the economic activities of the enterprises of investment and construction sphere into a new quality, achieving which will allow the implementation of innovative managerial solutions in construction of the objects of residential real estate will ensure the minimal consumption of natural resources, above all, thermal and energy resources.

The mentioned problems may be solved when the construction industry embraces the Green Building concept ${ }^{7}$. There are three main principles of ecoobjects: sustainable use of renewable resources (energy, water, land), assessment and minimization of the real estate item's negative impact on the environment at all its life cycle stages (in contrast to the existing focused normative approach to the evaluation of a construction's ecological safety at the design and construction stages only) and creation of a comfortable

${ }^{5}$ Econometric tools for managing construction companies' financial security [Text] : [monograph] / [L.V. Sorokina et al.]; under scientific supervision of professors Sorokina L.V. and Hoiko A.F. - Kyiv : Kyiv National University of Construction and Architecture, 2017. -403 pp.

${ }^{6}$ Theoretical and methodological framework of innovative and investment activities in Ukraine. / P.M. Kulikov, V.H. Fedorenko, H.M. Ryzhakova et al., collective monograph, LLC "DKS Center", Kyiv 2018. 442 pp.

${ }^{7}$ «Green Building -US EPA». Access mode: www.epa.gov 
"developing", environment for humans through the introduction of "green" standards.

According to the international standard ISO 26000:2010, sustainable development is the development that meets the needs of the present without compromising the ability of future generations to meet their own needs ${ }^{9}$. Sustainable development is about integrating the goals of a high quality of life, health and prosperity with social justice and maintaining the earth's capacity to support life in all its diversity. These social, economic and environmental goals are interdependent and mutually reinforcing. Sustainable development can be treated as a way of expressing the broader expectations of society as a whole. In this context, the implementation of the Smart City approach becomes the tool which can be introduced to improve people's quality of life and enhance the system of urban management and a city's sustainable development. A city may be considered smart, if investments into human and social capital, as well as into traditional (transport) and modern communication structure create the basis for sustainable economic development and high quality of life, with smart natural resource management thanks to grassroots governance.

According to the European smart city $\operatorname{model}^{8}$, smart cities are defined by six basic criteria/characteristics: 1) smart economy; 2) smart mobility; 3) smart environment; 4) smart people; 5) smart living; 6) smart governance. All these criteria correspond to the traditional urban development theories and are based on the widely accepted principles of regional competitiveness, transport and information and communication technologies, economics, natural resources, human and social capital, quality of life, as well as citizens' participation in urban management. For this reason, they were used as a basis of the 2007 rating, where 31 factor and 74 indicators correspond to the mentioned six characteristics ${ }^{10}$.

A previous analysis demonstrated that the division into categories and criteria of the analogs of the developed rating system for environmental friendliness and energy efficiency of houses in other countries is different. For example, BREEAM (Great Britain) - 9 categories and 48 criteria, DGNB (Germany) - 6 categories and 59 criteria, "Zelenyie Standarty" ("Green Standards") (Russia) - 10 categories and 46 criteria etc. This difference in the quantity (and, accordingly, in the contents) can be put down to the specific functions which have to be provided by the certification system and which depend on the existent climatic, resource, social and

\footnotetext{
${ }^{8}$ The smart city model. - Access mode: http://www.smartcities.eu/model.html

${ }^{9}$ ISO 26000 Guidance on social responsibility. Access mode: https://www.webcitation.org /672NbkWPg?url =htt p: //isotc .iso.org/static/

${ }^{10}$ Pokolenko V.O. Introducing the tools for choosing the alternatives of construction project implementation by functional and technical integrity of implementing organizations / Pokolenko V.O., Ryzhakova G. M., Prykhodko D.O. // Management of complex systems development. 2014. - Issue 19. - pp.104-108.
} 
cultural, economic conditions, regulatory and scientific and technical achievements of the country which developed the rating.

A formalized model of the dynamics of the state of biosphere-compatible urbanized territories in general is described by the following nonlinear equation:

$$
\frac{d x_{i}}{d t}=f_{i}\left(x_{1}, x_{2}, \ldots, x_{n}\right), i=1, n,
$$

where $f_{i}$ is continuous or sectionally continuous functions;

$x_{i}$ - coordinates of the system reflecting the state of a certain point on the phase plane or in the coordinate space and characterizing the state of the system's components at any moment in time.

As an evaluation criterion for the balance of biosphere-compatible urbanized territories, the quantitative ratio between its constituents' condition indicators, i.e.:

- the level of satisfaction of the needs in natural resources (so-called primary needs - water, oxygen, air, mineral raw materials etc.);

- the level of innovative development of infrastructure component in cities and settlements;

- the level of human potential development.

Mathematical representation of a dynamic system is determined by a set of non-linear differential equations:

$$
\left\{\begin{array}{l}
\dot{X}_{1}=a_{10} X_{1}-a_{11} X_{1}^{2}+\gamma_{1} X_{2} X_{3}-b_{1} Y+U_{10} \\
\dot{X}_{2}=a_{20} X_{2}-a_{22} X_{2}^{2}+\gamma_{2} X_{1} X_{3}-b_{2} Y+U_{20} \\
\dot{X}_{3}=a_{30} X_{3}-a_{33} X_{3}^{2}+\gamma_{3} X_{1} X_{2}-b_{3} Y+U_{30} \\
\dot{Y}=a_{40}-a_{44} Y^{2}+X_{1} X_{2} X_{3},
\end{array}\right.
$$

where $X_{1}$ is a variable characterizing the degree of natural resource consumption and the level of environment pollution by waste;

$X_{2}$ is a variable characterizing the level of development of manufacture and infrastructure component in the regions (the use of "green" technologies, number of innovative production facilities, rates of fixed asset renewal etc.);

$X_{3}$ is a variable characterizing the level of satisfaction of rational lifesupporting needs of urban populations (work, dwelling, education, healthcare, transportation etc.);

$Y$ is a variable presenting, on the system level, vital processes taking place simultaneously (synergy effect); 
$U_{10}, U_{20}, U_{30}$ are variables characterizing controlling actions directed at achieving the target state - compatibility with biosphere and progressive development of urbanized territories;

$a_{10}, a_{20}, a_{30}, a_{40}$ are feedback coefficients characterizing the influence of various environmental factors;

$a_{11}, a_{22}, a_{33}, a_{44}$ are feedback coefficients characterizing the stabilizing influence of external factors on the implementation of biosphere-compatible construction (e.g., the amount of anthropogenic and household waste recycled by an innovative, environmentally safe production and infrastructure component, has the effect of compensation of the adverse impact of a respective component on the environment)

$\gamma_{1}, \gamma_{2}, \gamma_{3}$ are coefficients characterizing the mutual influence between separate components and the elements of natural and sociological structures (indirect influence of air and water pollution level and other constituents of life sustenance on urbanized territories on population's health etc.);

$b_{1}, b_{2}, b_{3}$ are coefficients characterizing environment's stabilizing influence caused, for instance, by changes in legal framework, demographic processes, population's migration etc.

In Ukraine, the end-to-end maintenance of an investment and construction project, starting from the design stage up to the commissioning of the project, was novel until recently. However, this kind of management allows to predict, at various stages, the economic effects of general decisions taken at early and further stages of investment projects and to choose the efficient variant of project management and to timely correct its individual components to maximize the effect.

A changeover to project-oriented organizations is a global trend of the global community development caused by the fact that the technical and technological complexity of new products rises exponentially, life cycles shorten, but the expected value has to remain. This trend gives rise to conflicting demands and criteria for evaluating the projects concerning the creation of new products and services. Under such conditions, special significance is given to innovative mechanisms of project and program management based on convergence of knowledge and its system integration. The economic system of an enterprise is a complex integrated entity of spatially located elements, whose development is only possible provided that various kinds of production factors (material, technical, energy, labor, financial, and information) are optimally combined. At the current stage, special attention should be paid to the latter, as they ensure the efficient management of the use of other factors.

The rationale for an organization development project implementation should be based on the results of analysis of financial and operational activities (by main groups of indicators: financial, production, technological, economic etc.), market analysis (environment analysis: competitors, industry, consumers, market segment), analysis of efficiency of project proposals to be implemented 
(expenditures/payback period/development project profit: fixed asset acquisition, new production technology, separate production equipment units, marketing innovations, manufacture of new kinds of products, development of new kinds of activities, staff development etc.).

Based on the results of such analysis, the feasibility of implementation of the chosen development project is either confirmed or dismissed. In the case when the justification of a project's feasibility is incomplete of negative, the decision on development project implementation is cancelled.

In the second block, at the approval stage, investor is persuaded to invest money in the chosen development project. The enterprise's management exerts reflexive influence when it appeals to the investor's personal experience, which is substantiated by estimates. Table 1 contains details of reflexive strategies as an instrument of attracting investments for development projects for industrial enterprises.

The third block in the described approach is a practical one and foresees distribution of funds for development project investment and generating financial reports for the investor to consolidate the contact established at the previous stage.

Table 1

Behavior strategies of investment participants

\begin{tabular}{|c|c|c|c|}
\hline №1 & Participants & $\begin{array}{c}\text { Gains from investment } \\
\text { into a development } \\
\text { project }\end{array}$ & $\begin{array}{l}\text { Holding back from } \\
\text { investment into a } \\
\text { development project }\end{array}$ \\
\hline 1. & Investor № 1 & \multirow{2}{*}{$\begin{array}{c}\text { Profit-making, acquiring } \\
\text { positive experience }\end{array}$} & \multirow{2}{*}{ Loss of money } \\
\hline 2. & Investor № 2 & & \\
\hline 3. & Investor № 3 & $\begin{array}{l}\text { Profit-making, acquiring } \\
\text { positive experience }\end{array}$ & $\begin{array}{l}\text { Loss of money, risk of being } \\
\text { excluded from investment into } \\
\text { future potential projects by two } \\
\text { other investors }\end{array}$ \\
\hline 4. & $\begin{array}{l}\text { Construction } \\
\text { enterprise } \\
\text { management }\end{array}$ & $\begin{array}{l}\text { Improving competitiveness, } \\
\text { acquiring bonuses, } \\
\text { expansion of activities and } \\
\text { responsibilities }\end{array}$ & $\begin{array}{l}\text { Risk of being fired, loss of } \\
\text { investor's trust }\end{array}$ \\
\hline \multicolumn{4}{|c|}{ Investment object } \\
\hline 1. & $\begin{array}{c}\text { Project requiring } \\
\text { investment }\end{array}$ & Project is implemented & Project is not implemented \\
\hline 2. & $\begin{array}{l}\text { Construction } \\
\text { enterprise }\end{array}$ & $\begin{array}{c}\text { Getting effect from } \\
\text { development project } \\
\text { implementation, expansion } \\
\text { of activities, brand uprating }\end{array}$ & $\begin{array}{l}\text { Sale of enterprise in case of } \\
\text { failure of one or several } \\
\text { development projects due to } \\
\text { impossibility to bring the } \\
\text { enterprise on a totally new } \\
\text { development level. In this case, } \\
\text { sale is the optimum alternative } \\
\text { (while the brand retains its } \\
\text { positive impact) }\end{array}$ \\
\hline
\end{tabular}


The current operational environment construction enterprises find themselves in is characterized by a high agility and changeability of external and internal environment, globalization and transformation processes in the economy and the rising level of uncertainty and risk caused by these factors. This is why the organization of information collection systems at enterprises is very important to ensure that the processes on all levels of economic complex in the country and globally are overseen and managerial decisionmaking receives quality information support.

Today, such systems are built on the use of state-of-the-art information technologies, which allows to raise the response rate and other quality characteristics of information systems of modern enterprises. Increase in complexity and instability of economic processes lead to the change of the conditions of use of classical methods and approaches to the evaluation of information processes in place at enterprises, which necessitates the development and use of methodological approaches to their evaluation, as well as models and methods of analysis and forecasting their evolution dynamics, which allow to account for the uncertainty inherent to the process of modern economic systems development.

The real estate market in Ukraine had reach the development stage when construction organizations include into their business portfolio large projects which are technologically complex and financially intensive. As a rule, these projects deal with multifaceted objects, which make it possible for the enterprise to diversify the risks of the construction and try its hand in various segments of real estate. At the same time, multifaceted complexes are a very difficult format requiring a measured approach to the analysis, selection and distribution of functions, as miscalculations may influence the work's relevance and success.

\section{CONCLUSIONS}

It has been demonstrated that the analytical basis for forming an economic framework for investment mechanisms and provision of investment resources for real investments do not correspond to modern conditions of preparation and implementation of a residential construction cycle from its initial stage to commissioning of residential property complexes. This puts the need to renovate the methodological approach and tools of choosing economically sustainable economic and managerial mechanisms of residential construction and searching for sustainable variants of investment support for residential construction projects high on the agenda. It is noted that the modern features of work in a construction project require the office to act as a work coordinator for each separate project. It can be acknowledged that along with the complication of the nature of construction activities, classical symptoms of uncontrollability is 
observed at may construction enterprises: control over the launch, maintenance and development of projects is lost; managers' control over the operational activities of their structures weakens etc. In this regard, need arises to coordinate the managerial structure of a construction project in accordance with project management experience. On the basis of the proposed scientific and analytical approach to the administration of operational activities of the enterprises participating in the system of investment support of housing construction, comprehensive recommendations are developed aimed at differential attraction and evaluation of the sources of financial and alternative resources providing a wider range of possibilities to attract scarce resources than a functionally limited search of cash financing.

\section{SUMMARY}

The article is devoted to the development of scientific and methodological framework and tools for investment support of housing construction, which is considered in the context of mutual coordination with the specifics of economic and contractual relations of leading subjects of residential development - lender, developer, and investors. Methodological developments are based on the existing methodology of project management, the formation of a simplified and complete conceptual model of differentiated attraction of sources of resource support based on the theory of stakeholders, methods of economic assessment of sources of financing and attraction of investments and value-oriented goal-setting. The paper analyzes the existing concepts, models, methods of management of investment and construction projects, characterizes the current level of success of such projects. It was found that the housing project management system needs to be improved in terms of shifting the emphasis from maximizing the profit of builders to achieving the value of the project results for all its stakeholders throughout the life cycle of the project. The conceptual model of the problem-targeted differentiated choice of sources of resource support for investment and construction projects in housing construction is proposed.

\section{REFERENCES}

1. Econometric tools for managing construction companies' financial security [Text] : [monograph] / [L.V. Sorokina et al.]; under scientific supervision of professors Sorokina L.V. and Hoiko A.F. - Kyiv : Kyiv National University of Construction and Architecture, 2017. - 403 pp.

2. Theoretical and methodological framework of innovative and investment activities in Ukraine. / P.M. Kulikov, V.H. Fedorenko, 
H.M. Ryzhakova et al., collective monograph, LLC "DKS Center", Kyiv 2018. 442 pp.

3. Tetyana Marchuk, Dmytro Ryzhakov, Galyna Ryzhakova and Sergiy Stetsenko (2017). Identification of the basic elements of the innovative analytical platform for energy efficiency in project financing. Investment Management and Financial Innovations (open-access), 14(4), pp. 12-20. DOI: http://10.21511/imfi.14(4).2017.02

4. Pokolenko V.O. Introducing the tools for choosing the alternatives of construction project implementation by functional and technical integrity of implementing organizations / Pokolenko V.O., Ryzhakova G.M., Prykhodko D.O. // Management of complex systems development. - 2014. Issue 19. - pp.104-108.

5. Ryzhakova G.M. Models of targeted choice of representative performance indicators of construction companies: diagnostic systems etymology and typology / G.M. Ryzhakova, D.O. Prykhodko, K.M. Predun // Management of complex systems development. - 2017. Issue 32. - pp. 159-165.

6. Innovative development of an enterprise: textbook / V.G. Fedorenko, T.Ye. Voronkova, G.M. Ryzhakova; edited by V.G. Fedorenko, Kyiv, National University of Construction and Architecture, School of Economics of the National Academy of Sciences of Ukraine, V.G. Fedorenko, National Academy of Sciences of Ukraine, Kyiv : LLC "DKS Center", 2014 - 352 pp.

7. Chernyshev D. Formation of the methodical-analytical system of indicators of providing biosphere-compatibility at the preparation and organization of construction / D. Chernyshev // Management of complex systems development: Collection of scientific papers - Kyiv, KNUCA, 2018. - Issue 34 - pp. 191-198.

8. Chernyshev D. Implementation of principles of biospheric compatibility in the practice of ecological construction in Ukraine [Text] / D. Chernyshev, I. Ivakhnenko, G.Ryzhakova, K.Predun // International Journal of Engineering \& Technology - UAE: Science Publishing Corporation, 2018- Vol 10, No 3.2: Special Issue 2 - pp. 584-586.

9. Chupryna Y. The identification of alternatives and changes in scenarios for the development of regional build clusters [Text] / Y. Chupryna, D. Ryzhakov, O. Malykhina // International Journal of Engineering \& Technology - UAE: Science Publishing Corporation, 2018 Vol 10, No 3.2: Special Issue 2 - pp. 484-486.

10. Sharpe, W., Alexander, H., Bailey, J. Investments: translation from English. Moscow: INFRA-M, 2001. 1028 pp.

11. Residential housing financing schemes in Ukraine. Special features of attracting investments into construction [Electronic resource] // Materials of 
KLN Consult web-site // - Available at: http://www.kln.com.ua/content/ view/87/102/lang,ua

12. A.I. Rybak. Value-based management of investment and construction residential projects [Text] / A.I. Rybak, I.B. Azarova // Management of complex systems development. - 2013. - №24. - pp. 49 - 56.

13.Zeltser, R.Ya., Bielienkova, O.Yu, Novak, Ye.V., Dubinin, D.V. Digital Transformation of Resource Logistics and Organizational and Structural Support of Construction [Text] / Zeltser, R.Ya., Bielienkova, O.Yu, Novak, Ye.V., Dubinin, D.V. // Science and Innovation, 2019 Vol. 15(5) - pp. 38-51.

14. Izmailova K.V. The essence of economic cycles and their impact on the financial stability of construction [Text] / Izmailova K.V., Bielienkova O.Yu, Moholivets A.A. // Nauk. pr. NDFI, 2019 - Vol. 2 pp. 139-150.

15. Stetsenko S. The hierarchical model of evaluation of infrastructure risks / S. Stetsenko, T. Ilyina // Nauk. pr. NDFI, 2019. - Vol. 1. pp. 119-129.

16.Zeltser, R.Ya., Bielienkova, O.Yu. and Dubinin, D.V. 2018) Innovatsiini modeli i metody orhanizatsii, upravlinnia i ekonomichnoi otsinky tekhnolohichnykh protsesiv budivelnoho vyrobnytstva Kyiv: «MP Lesia», 2019 - 209 p.

17. Maksimov, A.S. Vakhovich, I.V. and other (2015), Enerhoefektyvnist' $\mathrm{v}$ munitsypal'nomu sektori [Energy efficiency in the municipal sector], Association of Ukrainian Cities under the USAID Project, Kyiv, Ukraine», 2015 - 254 p.

\section{Information about the author: Ryzhakova G. M.,}

Doctor of Economics, Professor, Head of Construction Management Department, Kyiv National University of Construction and Architecture 31, Povitroflotsky Avenue Kyiv, 03037, Ukraine 